\title{
Bioactive compounds from marine invertebrates for potential medicines - An overview
}

\author{
D. Datta ${ }^{1}$, S. Nath Talapatra ${ }^{2 a *}$, S. Swarnakar ${ }^{3 b}$ \\ ${ }^{1}$ Department of Zoology, Jogamaya Devi College, \\ 92 S. P. Mukherjee Road, Kolkata 700026, India \\ ${ }^{2}$ Department of Environmental Science, University of Calcutta, \\ 35 Ballygunge Circular Road, Kolkata 700019, India \\ ${ }^{3}$ Drug Development Diagnostic \& Biotechnology Division, \\ CSIR-Indian Institute of Chemical Biology, 4 Raja S.C. Mullick Road, Kolkata 700032, India \\ *a,bE-mail address: ecologylive@yahoo.co.in, sikta@iicb.res.in
}

\begin{abstract}
The present review deals with the bioactive compounds of the marine non-chordates. The potent medicinal usage of the bioactive compounds viz. steroids, terpenoids, isoprenoid and non-isoprenoid compounds, quinones, brominated compounds, nitrogen heterocyclics and nitrogen-sulphur heterocyclics from marine non-chordates have been compiled. Various literatures survey revealed that the bioactive compounds isolated in recent past from the marine poriferans, cnidarians, annelids, arthropods, molluscs and echinoderms could be rich sources of therapeutic agents having antibacterial, antiinflamatory, anticarcinogenic properties. In overall, the present study will be benefitted to know global drug discovery researches on bioactive compounds from marine organisms for students, scholars, scientists, pharmaceutical sector, and government regulating authorities as new challenging technology in clinical applications through medicines.
\end{abstract}

Keywords: Bioactive compounds; marine invertebrates; marine non-chordates; medicinal importance; zootherapeutic agents

\section{INTRODUCTION}

Marine natural products have attracted the attention to biologists and chemists all over the world for the last five decades. Approximately 16,000 marine natural products have been isolated from marine organisms and reported in approximately 6,800 publications as of date. In addition to these publications there are approximately another 9,000 reports, which cover syntheses, reviews, biological activity studies, ecological studies etc. on the subject of marine natural products.

In the animal world non-chordates constitutes an important component of study and the marine non-chordates comprises the major part. Multicellular non-chordates starting from the phylum porifera to echinodermata are normally found in the salt water and their ability to live in this halobiotic enviornment are due to their special adaptations, metabolic activities, secretions are all different from that of other animals and hence majority of them produce bioactive substances, which enables them to combat in that harsh environment. All members of the invertebrates utilize a 'plethora of substancesin'; their natural immunity ranging from 
peptides to alkaloids to trepenoids to steroids for defence and preservation of their natural integrity.

The ocean is considered to be a source of potential drugs and some of these bioactive compounds or secondary metabolites have biomedical potential. Oceans comprise $70 \%$ of the earth area and the marine ecosystems represent $95 \%$ of the biosphere. $33-34 \%$ animal phyla live in marine environment (Sima and Vetvicka, 2011). The marine life constitutes almost $80 \%$ of the world biota (McCarthy and Pomponi, 2004). The diversity of the species is extraordinary and in the tropical zones there are almost 1000 different species per square meter. Environmental pressure like competition for space, nutrition and self defence have led to the production of a diverse array of compounds called the secondary metabolites. These animals use the secondary metabolites for inter communication between themselves and their environment. These communication molecules evolved within the scope of symbiotic interrelationship.

The bioactive compounds generated majorly from marine animals are known as the secondary metabolites. These could be divided into steroids, terpenoids, isoprenoids, nonisoprenoids, quinones, brominated compounds, nitrogen heterocyclics, and nitrogen sulphur heterocyclics. Many of these molecules also represent ancient defence factors. Bioactive substances formed by marine organisms such as protozoans and invertebrates viz. poriferans, cnidarians, annelids, arthropods, molluscs and echinoderms have attracted attention due to their antiviral, antimicrobial, antiprotozoal, antifungal, antihelminthic and anticancer activities (Zapata and Amemiya, 2000). There are many researches on different metabolites of unusual structure and exhibiting biological activities (Erickson, 1983; Shimizu, 1993; Faulkner, 2002; Belarbi et al., 2003; Aneiros and Garateix, 2004; Garcia et al., 2007; Sima and Vetvicka, 2011; Alam et al., 2012; Kiran et al., 2014; Rahaman et al., 2014).

A vast number of bioactive compounds are produced by phylogenetically diverse organisms that have different and often unpredictable chemical activity and structure. They are small molecules, generally up to 3000 Daltons. Until the end of the first decennium of this century more than 15,000 natural compounds have already been isolated from poriferans, cnidarians, annelids, arthropods, molluscs and echinoderms. These compounds belong to various families of chemicals. Some of them have exotic structures. Their activities blocks metaboltic/enzymatic reactions, interrupts the cell cycle, effects phagocytosis and takes part in cellular killing etc. During the past few years a large number of novel compounds have been reported (Willams et al. 1989; Pomponi, 1999; Jimeno, 2002). Some of these compounds have studied clinical /preclinical trials and expected that they can be used as therapeutics in the near future.

In general, a large number of highly active antitumor compounds have been isolated from marine invertebrates. The best known examples include eleutherobin from Eleutherobia family of corals, sarcodictyin from Mediterranean Stolonigeran coral, the bryostatins from Bryozoan, Bugula neritine, and the dolastatins from the sea hare, Dolabell auriculata (May et al., 1987; Schmitz et al., 1993). Extracts of marine organisms being examined for antitumor compounds have been screened in a panel of about 60 human cancer cell lines in therapeutic areas of leukaemia, breast, ovarian, renal, prostrate, brain, colon, melanoma and lung cancers. The study of isolation of various chemical(s) as bioactive compounds from marine non-chordates and their medicinal usage have already been reported earlier internationally (Bergmann and Feeney, 1950; 1960; Burkholder and Sharma, 1969; Fenical and McConnel, 1975; Erickson, 1983; May et al., 1987; Willams et al., 1989; Schmitz et al. 1993; Faulker, 1995; Fuesetani, 2000; Towle et al., 2001; Faulkner, 2002; Jimeno, 2002; Belarbi et al., 2003; Aneiros and Garateix, 2004; McCarthy and Pomponi, 2004; Simmons et 
al., 2005; Zhang et al., 2006; Garcia et al., 2007; Kuramoto et al., 2008; Laport et al., 2009; Miller et al., 2010; Sima and Vetvicka, 2011; Alam et al., 2012; Bragadeeswaran et al., 2013; Kiran et al., 2014; Rahaman et al., 2014). There are also some scattered studies on bioactive compounds at national level (Chellaram et al., 2004; Santhana Ramasamy and Murugan, 2005; Chellaram et al., 2009; Maripandi et al., 2010; Sivasubramanian et al., 2011; Johnson et al., 2012; Bragadeeswaran et al., 2013; Dhinakaran and Lipton, 2014; Datta et al., 2014; Talapatra et al., 2014).

The present review aims to compile from different available literatures on bioactive compounds isolated from blood, tissues, cells and/or whole body of marine non-chordates that are of potential medicinal values.

\section{STUDY OF BIOACTIVE COMPOUNDS FROM MARINE INVERTEBRATESPECIES AND ITS POTENT MEDICINAL USAGE}

Marine life is fascinating and has great potential for development of drugs. The number of natural products isolated from marine organisms increases rapidly and now exceeds 18,000 (Marinlit, 2007; Faulkner, 1995; Faulkner, 2002; Proksch and Edrada, 2002). The modern idea of treatment of human ailment comprises of natural products with unusual structure and function derived from marine invertebrates. Some of these notable biodynamic agents of marine origin are cephalosporin, cytosine, saxotoin, didemins etc., which have clinical importance. The bioactive compounds viz. steroids, terpenoids, isoprenoid and nonisoprenoid compounds, quinones, brominated compounds, nitrogen heterocyclics and nitrogen-sulphur heterocyclics from marine non-chordates have compiled. (Table 1). The compilation of various literatures and study of bioactive compounds and their medicinal importance from marine non-chordates are as follows:

\subsection{Bioactive compounds from marine poriferans}

Sponges are traditionally rich sources of bioactive substances (McConnell et al., 1994). Even anti-malarial drugs like Manzamines are also reported from marine Sponges (Poriferas). The pioneering discovery of bioactive compounds from marine sources was the serendipitous isolation of C-Nucleosides, spongouridine and spongothymidine from Caribbean sponge Cryptothecaa crypt in early1950s. (Bergmann and Feeney, 1950). These compounds have potential antiviral activity and their synthetic analog was an anticancer drug (McConnell et al.,1994). Since, the first report of Manzamine A in 1986 and some 40 related compounds have been described from more than a dozen of species of Poriferas (Edrada et al., 1996). It has been reported that Manzamine A has potent antimalarial activity against rodent malarial parasite Plasmodium berghei in vivo (Ang et al., 2000). These compounds also include a variety of anticancer drugs like polyhyroxylated lactone, discodermlide isolated from the Caribbean Sponges Discodermia dissolute (Gunasekera et al., 1991). HTI-286, a synthetic analog of hemiasterlin (Nieman et al, 2003) originally isolated from a South African Sponge Hemiasterella minor (Talpir et al., 1994) and soon thereafter from Papua New Guinea Sponge from Cymbastela sp. (Coleman et al. 1995) and a synthetic analog (E7389) of Halichondrin B (Towle et al., 2001), which was originally isolated from a Japanese Sponge. There are several bioactive compounds viz. sterols, terpenoids, phenolic or quinoid, carotenoids etc. from marine sponges reported for medicinal values. Marine sponges are a good source of unusual sterols and these sterols have the function on biological membranes. The sulphated and 
alkaloid sterols have exhibited antimicrobial activity. A bioactive compound, halistanol was studied by Fusetani et al., (1981) from Halichondria mooriei, also halistanol sulfate from a marine sponge of the genus Aka (Mukku et al., 2003), halistanol trisulfate, a sulfated steroid derivative, was isolated from the extracts of two different marine sponges of genus Topsentia studied by Slate et al., (1995). It was reported by Townsend et al., (1992), the pigmented human melanoma cell line, MM418, became demelanized when treated continuously with a nontoxic level of halistanol trisulphate (HTS), a C29 steroidal detergent isolated from a marine sponge. According to Nakasu et al., (1983), the sterols from Toxadocia zumi inhibited the growth of two species of bacteria namely Staphylococcus aureus and Bacillus subtitis. A hydroxyl sterol with unusual features is isolated from Dysidea sp. (Gunasekera and Schmitz, 1983). There are two types of steroidal alkaloids viz. plakinamine A and plakinamine B as antimicrobial metabolites, were obtained from Plakina sp. and the compound was inhibited the growth of Staphylococcus aureus and Candida albicans (Rosser and Faulkner, 1984). The antimicrobial agent siphonodictyal-A and -B and have been isolated by Sullivan et al. (1981; 1983). The compounds viz. arenarol arenarone and illimaquinone from Dysidea arenaria, puupehenone from Hyrtios eubamma and sesquiterpene phenol from Smenospongia echina have been obtained by researchers ((Djura et al., 1980; Schmitz et al., 1984). Biologically active two compounds namely sesquiterpenoid and avarol, which was exhibited antimicrobial activity and also found active against "AIDS" virus was first isolated from a Mediterranean sponge Disidea avara (Minale et al., 1974) and later on from an Australian sponge Disidea sp. (Baker, 1976). Ent-chromazonarol, yet another interesting compound biogenetically related to avarol has been isolated from the marine porifera Disidea pallescens (Cimino et al., 1975; Barrero et al., 1999; Ishibashi et al., 2004). Also an interesting group of triprenyl phenols have been isolated from the red sponge Halichondria panacea (Cimino et al., 1973; Casapullo et al., 1993; Jaspars et al., 1995). Spongia officinalis, the common bath sponge is a rich source of terpenoids. Antifungal and antimicrobial activities have been reported in the tetracyclic furanoditerpenes isolated from sponge $S$. officinalis. Spongia-13, 14-dien-19-oic acid (Djerassi, et al., 1979) spongia-13-14-dien-19-al and spongia-13--14-diene are isolated by Capelle et al., (1980) from the same species diterpenes have also been isolated. Gonzalez et al., (1984) reported diterpenoids containing a purine or a 9-methyladenine unit (Djerassi, et al., 1979). These compounds exhibit antimicrobial and Na, K-ATPase inhibitory activities. According to Funel et al., (2004) novel bicyclic and monocyclic diterpenoids with a 9methyladenine unit possessing inhibitory effect on $\mathrm{Na}, \mathrm{K}$-ATPase have been isolated from sea sponge Agelas nakamurai. A series of tricyclic diterpenes having isocyano, hydroxyl, tetrahydropyranyl and chlorine functions and exhibiting antibiotic activity were isolated from Acanthella species (Patra et al., 1984; Tsukamoto et al., 2003). Many species of genus Spongia contain biosynthetically intriguing C21 difuranoterpenes probably derived from linear sesterterpene tetronic acid. Luffarella variabilis has furnished four sesterterpenoid antibiotics (De Silva and Scheuer, 1980; 1981). Several tetracarbocyclic sesterterpenes have been isolated from Cacospongia scalaris (Yasuda and Tada, 1981). The bioactive compound showed cytotoxicity against the P-388 cell lines (Liu et al., 2004). The compounds from this sponge also exhibit antifungal and antiinflammatory activities (Roy et al., 2002). Phyllofenone A and 20,24-diethyl-25-norscalorane sesterterpene with antifungal activity from sponge Phyllospongia foliascens (Pallas) have been isolated by Kimuchi et al., (1981; 1983). Sokoloff et al., (1982) have investigated norsesterterpenoid peroxide antibiotics from the Red Sea sponge Prianos sp. The peroxides strongly inhibit the growth of Gram-positive bacteria (Crews et al., 1985). Further, several carotenoids have been isolated from marine sponges (Litchfield et al., 1980; Sliwka et al., 1987; Santoro et al., 1990; Loya et al., 1992; Lysek et 
al., 2003). Sponges also elaborate unusual compounds from tyrosin and tryptophane. Brominated tryptamines from Smenospongia sp. exhibited antimicrobial activity (Djura et al., 1980). Methyl-aplysinopsin from Aplysinopsis reticulate, is a short acting inhibitor of monoamine oxidase was reported by Taylor et al., (1981). Numerous drugs from marine sponges have been identified as a source of targeting microtubules (Zhou and Giannakakou, 2005; Miller et al., 2010). The anti-cancer activity of these agents may lie mainly in their inhibitory effects on spindle microtubule dynamics, rather than in their effects on microtubule polymer mass (Zhou and Giannakakou, 2005). Substances such asjaspolide, dolastatin, halichondrin, spongistatin, hemiasterlin, dictyostatin, dis-codermolide, laulimalide, peloruside A and zampanolide infuence function of the cytoskeleton similar (Kingston, 2009; Saito, 2009). Among marine invertebrates, Porifera (sponges) are potential source of novel bioactive compounds to provide future drugs against malaria, cancer and a range of viral diseases was reviewed and documented by (Ravichandran et al., 2007). Sima and Vetvika, (2011) have documented the clinical use of secondary metabolites for the therapy of cancer from marine poriferans. Johnson et al., (2012) have studied in vitro antimicrobial activity of marine sponge Zygomycale sp. collected from Kanyakumari coast (south east coast of India). The sponge extract was tested against nine human bacterial pathogens and four human fungal pathogens, and it was revealed that, the extracts showed potent antibacterial activity against bacteria such as Bacillus megaterium, Klebsiella pneumoniae and Sterptococcus pyogenes and it exhibited antifungal activity against all pathogenic test strains. Hardoim and Costa, (2014) have reviewed that several bioactive terpenoids and polyketides have been retrieved from Irciniidae sponges, but the actual producer (host or symbiont) of these compounds has rarely been clarified.

\subsection{Bioactive compounds from coelenterates}

Cnidarians are the richest natural sources of prostaglandins, so far discovered in the soft coral Plexaura hamomala found on Caribbean Sea. Bioactive substances have also been procured from bryozoans (Carle and Christophersen, 1980).

There has been much interest in the metabolites of jelly fish, sea nettle, the Portuguese man-of-war and the sea wasp which are widely distributed in warm tropical seas. The organisms release nematocyst venom from the tentacles which causes painful injuries. The venoms are generally a complex mixture of enzymes and pain-producing factors. The nematocyst venom of $P$. physalis is a mixture of toxic proteins and enzymes, which showed multiple action including dermonecrosis, neurotoxicity, hemolysis and cardiotoxicity (Carle and Christophersen, 1980; Banduraga et al., 1982).

Several species of sea anemones produced toxins that are polypeptides or proteins in the sea coasts of the Andaman and Nicobar islands. The toxins are found very useful tools for studying the voltage dependent $\mathrm{Na}+$ channels in nerve and cardiac muscle cells. It has been suggested that coelenterate toxins would be suitable for studies of tumor cell cytolysis in vitro and in vivo (Fusetani et al., 1981; Kobayashi et al., 1984; Groweiss et al., 1985).

Some of the soft corals that occur in the Andaman and Nicobar Islands are horny gorgonians, sea fans, the red organ-pipe coral, the blue coral, Helipora sp. and mushroom coral Fungia sp. The coral Clavularia viridis has yielded cytotoxic steroids, stoloniferones AD (Kobayashi et al., 1984). Soft corals were elaborated a large variety of sesquiterpenoids and diterpenoids. Several of these compounds were reported as toxic. Guaiazulene from the gorgonian Euplexaura erecta exhibited mild activity against Pseudomonas aeruginosa (Fusetani et al., 1981). Subergorgic acid, a cardiotoxin is obtained from the pacific gorgonian 
coral Subergorgia suberosa (Groweiss et al., 1985). The toxin was inhibited neuromuscular transmission at $0.16 \mu \mathrm{g} / \mathrm{mL}$ in isolated guinea-pig heart assay. Pseudopterolide, an unusual diterpene with a 12 member ring from the gorgonian Pseudopterogorgia acerosa showed unusual cytotoxic properties (Banduraga et al., 1982).

The marine bryozoan, Flustra foliacea has yielded several brominated alkaloids called flustramines division of the fertilized sea urchin eggs (Wright, 1984). The bryozoan Phidolopora pacifica has yielded phidolopin, a purine derivative largely responsible for high order of antifungal and antialgal activities (Ayer et al., 1984; Hirota et al., 1985; Avasthi et al., 1996). Several macrolides like bryostatin-1 and bryostatin-2 were isolated from Bugula neritina. Some of these metabolites were showed high order of antineoplastic activity (Pettit et al., 1982; 1983a; b). The compounds such as [2-Hydroxyethyl]dimethyl sulfoxonium ion acts as an allergen and were isolated from marine bryozoan Alcyonidium gelatinosum (Carle and Christophersen, 1980).

The glycosides, cervicosides and prostanoid sclaviridenones, from the soft corals Sinularia cervicornis and Clavularia viridis were shown to have antitumor activity against human cancer cell lines (Zhang et al., 2006). The polyoxygenated steroids from Alcyonum patagonicum and another coral species (Nephtea erecta) were represented the most numerous group of coral diterpenoids, which have mild-to-strong cytotoxicity to the human tumor cell lines CCRF-CEM and DLD1 (Duh et al., 1998). Another cytotoxic and cytostatic compounds from soft coral were eleutherobin (Lindel et al., 1997; Long et al., 1998) and sarcodictyin (Burres et al. 1991; Hamel et al. 1999), which interfered with microtubulins by increasing polymerization. It was observed and reported by McDaid et al., (1999) that in addition, abovementioned natural product was shown a potent cancer cell inhibitor with an IC50 similar to that of paclitaxel (Taxol $\left.{ }^{\circledR}\right)(10-15 \mathrm{nmol} / \mathrm{L})$, and assays were carried out in the National Cancer Institute's 60 cell line panel showed a 100 -fold greater potency over the mean cytotoxicity towards breast, renal, ovarian and lung cancer cell lines. Secondary bioactive metabolites were also discovered in gorgonians. They are mainly steroids and terpenoids and several lipid compounds. The strong and selective cytotoxicity was documented for the oxygenated lactones (menverins) from Menella verrucosa (Li et al., 2008). Furean sesquiterpenoids from Torilis japonica exhibited signifcant cytotoxicity toward the growth of A549, HT-29, KB, P-388 and P-388 cells (Park et al., 2006). Sima and Vetvika, (2011) have documented the clinical use of secondary metabolites for the therapy of cancer from marine coelenterates. They have documented the clinical use of secondary metabolites for the therapy of cancer from marine coelenterates. Generally all substances with bioactive activities mainly steroids, terpenes, and other compounds (e.g., ceramides) were obtained from sea anemones and corals (Anthozoa). A great number of diterpenoids classifed into the dollabelane, xenicane, phenylgermacrane, and cembranegroups were showing cytotoxicity against cancer cell lines isolated from Nepheta sp., also the clavulactones, clavirolides and clavudiols isolated from Clavularia sp. According to Japanese Foundation for Cancer Research 39 cell line assay, these compounds were examined for growth-inhibition activities in vitro toward human cancer cells and reported in the results that moderate cytotoxic activity against human colorectal adenocarcinoma cells (DLD-1) with an IC50 of $5.0 \mu \mathrm{g} / \mathrm{mL}$. The lobane diterpenes and lobane lacatnes, the pacifns from Sinularia sp. and Lobophytum sp. appeared similar cytotoxicity. A number of diterpenoids of the xenicane groups from Xenia sp. exhibited mildto-potent cytotoxic activities against human lung carcinoma (H460) and liver carcinoma (HepG2) cell lines (Su and Wen, 2011). The cembrane substances mainly from Sinularia triangular were isolated by Su and Wen, (2011). 


\subsection{Bioactive compounds from annelida}

Marine polychaete (phylum Annelida) has been found to treat several pathophysiological conditions such as arthritis, osteoporosis, bone cancer etc. The bioactive compound has been isolated from a marine annelid, Arenicola marina by Mynderse et al., (1997). The compound arenicins are 21 residue peptides, which were completely killed $E$. coli within 5 mins at a concentration of $5 \mu \mathrm{M}$ probably by membrane permeablization (Ovchinnikova et al., 2004). Another peptide named perinerin from annelid has been purified from the clamworm Perinereis aibuhitensis (Pan et al., 2004). The most important antimicrobial peptide (AMP) to be isolated from marine annelid is Hedistin. It is purified from the ragworm, Nereis diversicolor. Both native and synthetic hedistins are active against Gram-positive and Gram-negative bacteria (Tasiemski et al., 2007). The potent bioactive compounds from marine polychaete Glycera dibranchiata have been isolated by Chain and Anderson, (1983). According to them, coelomic fluid of this annelid exhibited antibacterial activity. Elayaraja et al., (2010) reported that the water, methanol and acetone extract from the whole body tissue of polychaete Perinereis cultrifera has potent antibacterial and antifungal activities. Among all the extracts, methanol showed maximum antibacterial activity against Staphylococcus aureus $(8.0 \mathrm{~mm})$ and minimum against Klebsiella oxytoca $(1.0 \mathrm{~mm})$ both in methanol and acetone extracts. For antifungal pathogens, methanol extract showed maximum activity against Rhizopus sp. (12.0mm) and minimum against Aspergillus niger $(2.0 \mathrm{~mm})$ in the water extract. Also the trace activity was noticed in another fungal species such as Mucor spp. and Aspergillus niger in both water and acetone extracts.

\subsection{Bioactive compounds from arthropoda}

Several bioactive compounds have also been isolated from marine arthropods. From marine arthropods, the most remarkable bioactive substance is Limulus Amoebocyte Lysate (LAL). It is an aqueous extract of blood cells (amoebocyte) from horseshoe crab Limulus polyphemus. LAL reacts with bacterial endotoxin or lipopolysaccharides (LPS), which is a membrane component of Gram negative bacteria. The reaction is the basics of LAL test that is used for the detection and quantification of bacterial endotoxin (Hurley et al., 1991). Fred Bang reported in 1956 that Gram negative bacteria even if killed will cause the blood of horseshoe crab to turn into a semisolid mass. It was later recognised that the animal's blood cells, mobile cells called amoebocyte, contains granules with clotting factor known as Coagulogen. In 1970, the US Food and Drug Administration (FDA) approved LAL for testing drugs, products, and devices that come in contact with blood. Prior to date much slower and expensive test were done on rabbits for the purpose. The underlying defence mechanism of the horseshoe crab, a marine arthropod remains to be solved which has survived for millions of years as a 'living fossils'. An agglutinin named limulin was discovered in Limulus polyphemus, which is a sialic acid binding lectin. It was proposed to play some role in host defence mechanism. However, Indian variety horseshoe crab, Carcinoscorpius rotundacauda containing sialic acid binding lectin carcinoscorpin, which acts as an opsonising agent like vertebrate antibody. It is provided higher host resistance for an induced circulatory level and enhanced rate of phagocytosis for lectin opsonised bacteria thus playing the role of a humoral factor as in vertebrate-'C' reaction protein of vertebrates (Basu et al. 1995). Foreign cell cytolysis by limulin represents a novel function for a plasma lectin and is the first documented function for limulin (Armstrong et al., 1996). Armstrong et al., (1998) have reported that in case of hemolysis, alpha2-macroglobulin was not involved directly when unreacted but 
instead that methylamine-reacted alpha2-macroglobulin inhibits the hemolytic activity of limulin (plasma lectin). Thus the thiol ester proteins alpha2-macroglobulin from Limulus polyphemus and C3 from mammals operate very differently in the hemolytic systems.

Shrimp is one of the most popular seafoods worldwide, and its lipids have been studied for biological activity in both, muscle and exoskeleton. Free fatty acids, triglycerides, carotenoids, and other lipids integrate this fraction, and some of these compounds have been reported with cancer chemopreventive activities. Carotenoids and polyunsaturated fatty acids have been extensively studied for chemopreventive properties, in both in vivo and in vitro studies. Their mechanisms of action depend on the lipid chemical structure and include antioxidant, anti-proliferative, anti-mutagenic, and anti-inflammatory activities, among others. These are Astaxhantin esters, $\beta$-criptoxanthin, $\alpha$-carotene, $\beta$-carotene, meso-zeaxanthin, canthaxanthin, lutein, zeaxanthin, and crustacyanin (López-Saiz et al., 2013).

According to Kiran et al., (2014), sea invertebrate Ozius rugulosus (Crustacean) was tested for antibacterial activity against human pathogens Acinetobacter baumannii, Pseudomonas aeruginosa and Escherichia coli K1. The best results were obtained by methanol extracts compared to aqueous extract of selected sea animal against Pseudomonas aeruginosa. According to them, this preliminary information about the antimicrobial activity of invertebrates from Manora channel in south of the city of Karachi for potential use in the development of new antibiotics.

Recently Datta et al., (2014) have carried out a work on peanut worm (P. archuata) belonging to the rare phylum sipunculida. In this study it was found that the lectin activity in the hemolymph of the rare Peanut worm found exclusively in the Sunderban deltaic region beside the amoebocyte present in the hemolymph was showed phagocytic activity indicating the role of this hemolymph in defence mechanism (Lombardo and Blanco, 2012). Venomous arthropods are a rich source of bioactive compounds evolved for prey capture and defence against predators and/or microorganisms. These highly potent chemical arsenals represent an available source for new insecticidal compounds as they act selectively on their molecular targets. These toxins affect the invertebrate nervous system. Also some small peptides with 'newly exploited' biological activities such as vasoactive, hormone-like and antimicrobial activities were found (Pimenta and De Lima, 2005; Schwartz et al. 2012; Tincu and Taylor, 2004). Talapatra et al., (2014) have recently studied biochemical characterization of hemolymph of fiddler crab species, Uca rosea. Hemolymph of U. rosea male exhibited protein bands having molecular size ranging from $137-42 \mathrm{kDa}$ and in female having $137-$ $27 \mathrm{kDa}$. The observed band $\sim 42 \mathrm{kDa}$ for both female and male suggesting the presence of hemolin protein that attributed to immune response. Both male and female showed band around $72 \mathrm{kDa}$ indicating the presence of haemocyanin protein.

\subsection{Bioactive compounds from molluses}

A bioactive compound was isolated from the Hawaian mollusk, Elysia rufescens (Hanmann et al., 1993; 1996) spisulosine, isolated from the marine clam, Spisula polynyma (Hanmann et al., 1993). Dolatriol, isolated from marine mollusca Dollabella auricularia has pronounced antileukemic activity. Synthadotin, Soblidotin are two synthetic analogues of Dolstatin isolated from molluscan species $D$. auricularia, which are in trial for medicinal properties.

Several bioactive compounds viz. steroidal, terpenoids, and acetylenic compounds isolated from nudibranchs and the same compounds were also reported in sponges which these nudibranchs feed upon (Cimino et al., 1980). The bioactive nucleoside characterised as 1-methyl-isoguanosine has been found in the nudibranch Anisodoris nobilis (Fuhrman et al., 
1980; Kim et al., 1981; Grozinger et al., 1983). It is interesting to note that bioactive compound as N-glycolylneuraminic acid-specific lectin (PAL) purified from an albumin gland extract of the apple snail, Pila globosa found in freshwater (Swarnakar et al., 1991) that compound may also found in marine gastropods. A bioactive compound Isoguanosine was isolated for hypotension and relaxation of smooth muscles in mammals from marine nudibranch Diaulula sandiegensis (Fuhrman et al., 1981). Another compound Hexadecylglycerol was isolated from Archidoris montereyensis showed antibacterial activity in vitro against Staphylococcus aureus and Bacillus subtilis (Gustafson and Andersen, 1985). It was known that sea-hares accumulate large quantities of metabolites in their digestive gland and skin. These compounds were believed to originate from the algae, which they feed. Aplysiatoxin, a toxic metabolite has been isolated both from the Hawaiian sea-hare Stylocheilus longicauda and also from blue-green alga Lynbrya majusticula on which it feeds (Moore et al., 1984). Aplysistatin is a well known antileukemic metabolite from the sea-hare Aplysia angasi (Hoye et al., 1982). The metabolites of Aplysia dactylomela were reported as cytotoxic and antitumor activity in vivo (Schmitz et al., 1981). The mollusc species Dolabella auricularia has been reported for yielding several antineoplastic and cytotoxic compounds named dolastatins. (Pettit et al. 1981; 1982, Harrigan et al. 1998; Poncet et al. 1999; Luesch et al., 2002). It was reported that marine snails of the family conidae synthesized potent toxins when they inject into their prey by means of a hollow tooth in order to immobilised their prey. Few species are known to cause injuries to humans and have proved fatal. The venom of Conus geographus is most dangerous to man. A bioactive compound striatoxin, a cardiotonic glycoprotein was obtained from Conus striatus that was reported to have long lasting isotropic action on guinea-pig left atria (Kobayashi et al., 1982). The bioactive compound, Zinconitide isolated from a snail, Conus magnus, is licensed by Elan Pharmaceuticals under the name Prialt and is used for intratracheal treatment for chronic pain. Dollastains are highly active anti-tumor compounds isolated from a sea slug. In some cases potentially interesting compounds have been isolated from molluscs, a HIV virus-inhibiting compound from the green mussel Perna viridis has been studied and patented (Berge et al., 1997). Kelletinin-I and II isolated from marine mollusc, Kelletia kelletii inhibited the growth of Bacillus subtilis and L1 leukemia cells as antibacterial and anticancer agents (Fuhrman et al., 1981; Tymiak and Rinehart, 1983). It was reported that Surugatoxin and neosurugatoxin were isolated from Japanese ivory shell, Babylonia japonica (Kosuge et al., 1981; 1982) and it was found that the antinicotinic activity of the latter is found to be 100 times that of the former. The antibiotic diemensin A and diemensin B was found in another mollusc species Siphonaria diemensis (Kosuge et al., 1982). The former was inhibited the growth of Staphylococcus aureus and Bacillus subtilis at $1 \mu \mathrm{g} / \mathrm{disc}$ and $5 \mu \mathrm{g} /$ disc, respectively. It was also reported to inhibits cell divisions in the fertilized sea-urchin egg assay at $1 \mu \mathrm{g} / \mathrm{mL}$. A potential polysaccharide with potent antibacterial and antifungal activity was extracted from the cuttle bone of Sepia aculeata and Sepia brevimana. Polysaccharide isolated from these cephalopod species were studied for their antibacterial and antifungal activity against nine bacterial species (Bacillus subtilis, Escherichia coli, Klebsiella pneumoniae, Vibrio cholerae, Vibrio parahaemolyticus, Staphylococcus aureus, Pseudomonas aeruginosa, Salmonella typhii and Shigella sp.) and four fungal species (Candida sp., Rhizopus sp., Aspergillus flavus and Aspergillus fumigatus) pathogens at different concentrations such as 25, 50, 75 and 100\% against control. The activities were found to be increasing with the increasing concentration of the extracts. No antibacterial activity was recorded against $V$. cholerae in all concentrations of $S$. brevimana. In $S$. aculeata, maximum and minimum activity was recorded against $E$. coli, but in $S$. brevimana the highest and lowest activity was recorded against $P$. aeruginosa and $E$. coli, respectively. In the antifungal activity study, the highest and lowest inhibition zones were noted against $A$. flavus, Candida sp. and A. fumigates and Rhizopus sp. respectively, but in $S$. brevimana, maximum and minimum activity were observed against $A$. flavus and $A$ 
fumigatus, respectively. In both species the cuttlebone polysaccharide showed no activity against Candida sp. (Shanmugam et al., 2008). Anbuselvi et al., (2009) have studied on bioactive compounds of coral associated gastropod, Trochus tentorium against the human pathogens as potent antibacterial activities. The mollusc species, Trochus tentorium was extracted as whole body with four solvents such as acetone, ethyl acetate, dichloromethane and methanol. Maximum antibacterial inhibition zone was showed from acetone crude extract of this species against Streptococcus pneumonae and Klebsiella pneumonae. The minimal inhibitory concentration of the $100 \%$ acetone fraction of $T$. Tentorium was reported lower in case of pathogens like E. coli, Streptococcus pneumonae, Staphylococcus aurues and Vibrio cholerae. Sivasubramanian et al., (2011) have studied new bioactive compounds from marine mollusc Melo melo. According to them, antibacterial activities were recorded as maximum zone of inhibition against Klebsiella pneumoniae (K. pneumoniae) strain of the mucus extract and minimum zone of inhibition in Salmonella typhi (S. typhi) strain of body tissue extract. The antifungal activities of the extracts for maximum activity against Trichophyton mentagarophytes (T. mentagarophytes) and minimum activities in Aspergillus flavus ( $A$. flavus) were observed. The extract of mucus, nerve tissue, body tissue and kidney that showed antimicrobial activity due to the presence of the peptides and amide groups. The extracts from marine molluscs $M$. melo is the potential source of antibacterial and antifungal bioactive compounds. It was also reported that the ink secretion of molluscan species was identified as one of the novel sources of bioactive compounds. Aqueous ink extracts of Dollabella auricularia inhibited the growth of Gram-positive and Gram-negative bacteria. In addition to D. auricularia, Octopus vulgaris and Sepia aculeate ink samples showed antifungal activity. The antimicrobial activities of the samples were not due to the presence of protease activity. All tested ink samples were not shown the property of agglutinating chicken erythrocytes. The $D$. auricularia ink fluid was haemotoxic that showed $100 \%$ lyses of chicken RBC with the minimum concentration of protein $4.4 \mu \mathrm{g} / \mathrm{ml}$. In plasma coagulation assay $S$. aculeate ink showed procoagulant property and it coagulated chicken plasma within $180 \mathrm{~s}$; all the remaining samples took time more than $5 \mathrm{~min}$ for clot formation. It was also found that specific roles in the chemical defense mechanism of inking mollusc species (Vennila et al., 2011).

It was observed in a preliminary study about the antimicrobial activity of invertebrates from Manora channel for potential use in the development of new antibiotics. The methanol extracts and water extracts of marine molluscs, gastropods tested against 3 bioflm bacteria which showed antibacterial activity. The overall screening showed highest activity in gut of Perna viridis $(99.63 \%$ ) against $P$. aeruginosa. Low activity was observed in gonad of Perna viridis against $E$. coli $\mathrm{K} 1$. Other Methanol extracts were also able to produce bacterial inhibition against $E$. coli K1, A. baumannii and P. aeruginosa (Kiran et al., 2014).

\subsection{Bioactive compounds from echinoderms}

The metabolites of Echinoderms as bioactive compounds mainly are saponins. These are found in sea-urchins, starfishes, sea cucumber etc. The chemistry and biological activities of bioactive saponins have been reviewed by (Scheuer, 1988). Another bioactive compounds at asterosaponins were reported as hemolytic, antineoplastic, cytotoxic, antitumor, antibacterial, antiviral antifungal and antiinflammatory activities (Leung and Stefano, 1983; 1984). Asterosaponins are sterol derivatives, while saponins from sea cucumber were reported terpenoid in nature. Both groups have sulphate esters and quinovose sugar moieties. However, in asterosaponins the sulphate function is attached to an aglycone, while it has attached to the carbohydrate moiety in some sea cucumber saponins. It was also reported that the saponins from other sources lack sulphate functionality. As of year 1986, the saponins of over 50 sea 
cucumbers have been studied (Stonik, 1986). Many cerebrosides, pyrimidine nucleosides, thymine deoxyriboside and uracil deoxyribose have been isolated from the starfish Acanthester planei (Komori et al., 1980).

Pedicellaria of some species of sea-urchins contained toxic substances. Extract of Toxopneustes pileolus causes histamine release from isolated smooth muscles (Kimura, and Nakgawa, 1980). The extract of the organism produced contraction of the longitudinal muscles of isolated guinea-pig ileum at a concentration of $3 \times 10-8 \mathrm{~g} / \mathrm{mL}$. There are two types of echinoderms namely Lytechinus variegates and Strongylocentrotus droebachiensis have yielded for antineoplastic glycoproteins (Pettit et al., 1981a; b). Linhardt et al., (1990) have reported that low molecular weight sulphated polysaccharides were noted from sea cucumbers with efficient anticoagulant activities and several pharmacological properties. The chondroiton and glucosamine components of holothuria were reported to be important cartilage building blocks and other bio activities including anti-inflammatory and antitumor activity properties (Herecia and Ubeda, 1998).

The bioactive compounds were reported to act as the chemokine receptor subtype-5 (CCR5) with possible anti-HIV activity from the sea cucumber species, Telenata ananas (Hegde et al., 2002). Bioactive compounds isolated from sea cucumber species S. liouvillei containing chondroitin sulphate (the polysaccharides) that exhibits antiviral activity to inhibit human immuno deficiency virus (HIV) infection (Chen, 2003). Fuscocineroside C bioactive compound atriterpene glycoside was obtained from sea cucumber Holothuria fuscocinerea that showed cytotoxic nature against human cancer cells (Zhang et al., 2006). According to Zou et al., (2005), Intercedenside D-I isolated a cytotoxic triterpene glycoside from the sea cucumber Mensamaria intercedens a marine natural product inhibited proliferation of several human cancer cell lines. Wu et al., (2006) have studied that Hillaside C a triterpene derived from sea cucumber Holothuria hilla inhibited the growth of human leukemia, breast and colon cancer cells invitro in a dose and time-dependent manner by a mechanism that required induction of apoptosis and the concomitant reduction of the apoptosis-suppressing protein Bcl-effect. The bioactive compounds as steroid glycosides are a class of wide spread natural products having marine origins. Spirostan and furostansteroid saponins, pregnane glycosides have a potential to be used as cancer therapies. Structurally, these glycosides exhibit a moderate cytotoxicity against human leukemia cell lines (Prassas and Diamandis, 2008). The extract LPS obtained from Stichopus japonicus induced inflammatory response via blocks the MAPK signalling pathway inmurine macrophages, showed invitro with anti-inflammatory potential Himayaa et al., (2010). In recent findings, Rahman et al., (2014) reported that many species of sea urchin male and female gonads are rich in valuable bioactive compounds viz. polyunsaturated fatty acids (PUFAs) and $\beta$-carotene. PUFAs, especially eicosapentaenoic acid and docosahexaenoic acid, have significant preventive effects on arrhythmia, cardiovascular diseases and cancer. $\beta$-Carotene and some xanthophylls have strong pro-vitamin A activity and can be used to prevent tumor development and light sensitivity. The sea cucumber (Holothuriaatra) extracts have been evaluated for the presence of bioactive compounds and various biological activities. The methanol extracts showed antiproliferative activities against the Hela and MCF-7 cell lines. Similarly the inhibitory effects of Herpes simplex virus 1 and 2 cells were detected using the plaque reduction assay. The extracts of $H$. atra were purified using the silica gel column chromatography and the active fractions showed antimicrobial activity. The studies were carried out on Staphylococcus aureus MTCC737, E. coli MTCC443, Klebsiella pneumonia MTCC109, Listeria monocytogenes MTCC1143, and Serratia liquefaciens MTCC3039 (Dhinakaran and Lipton, 2014). 


\section{CONCLUSIONS}

The marine biota has its vastness of living organisms along with their multiplicity and biodiversity. It provides an immense source of unique life with many special characteristics. Life in fact, first originated in water hence, the marine life had an ample time to evolve and flourish in its own way showing its diversity and variety. This marine organism has numerous ways to combat the intrinsic, extrinsic and environmental factors. They have developed morphological, physiological and biochemical techniques to save themselves in this environment. Hence, the bioactive substances produced by them are in one way unique and essential for their survival. These bioactive substances are utilised by them in their various spheres of living like, growth, reproduction, communication, protection, defence, locomotion etc which have complex structural composition and found to have functional significance to humans. Thus marine organism has served as a source of medicine and pharmaceutical since ancient times. The body extracts of various marine organisms have cured various diseases which researchers have tried to study from various angles. The structure and mode of action of few bioactive compounds become known to the medical world. Numerous pharmaceutical companies are involved in solving new actions of bioactive compounds from marine sources. Although no major therapeutic drugs has yet been developed from the sea, but reports of anticancer, anti-inflammatory, anti-microbial wound healers are known.

Drug discoveries from marine non-chordates have an important research field since decades. Currently, interest in evaluating marine invertebrate products, with the aim of obtaining new potential disease preventive drugs with few side effects, is still growing. In many cases, the bioactive compounds from marine organisms are difficult to obtain in sufficient amounts and researchers, therefore, have to start mimicry mother nature for preparation of synthetic compounds or drugs.

The rich diversity in bioactive compounds from invertebrates have provided molecules that interfere with the prevention of a disease at many different points, which increase the chances of developing selective drugs against specific disease(s). Marine invertebrates have provided many examples of novel secondary metabolites that possess varied chemical status and potent antimalarial, antiinflamatory, anticarcinogenic, antibacterial, antifungal etc. activities (Table 1).

The Sunderban deltatic region of India has a unique not found elsewhere in the world. Future studies on mangrove biota may serve as a rich source of information as well as pharmaceuticals significance. In this context recent finding with $P$. archuata may usher a new field of processing bioactive substances from marine invertebrate available in Sunderban deltatic region. It is also very important to know the presence of bioactive compounds in fiddler crab species inhabited in the same geographical region and/or other mangrove area.

Marine natural products also provide a novel and rich source of chemical diversity that can contribute to design and development of new and potentially useful therapeutic drugs. The data from available literatures reveal that the marine ecosystem is not only the resources to discover various bioactive agents but also an avenue to identify new cellular targets for drug discovery. A proactive interaction among research scholars, scientists, pharmaceutical sector, and government regulating authorities is important to the incorporation of this challenging new bioactive agent in clinical applications. 
Table 1. The most important bioactive compounds isolated from marine non-chordates.

\begin{tabular}{|c|c|c|}
\hline $\begin{array}{l}\text { Marine sources } \\
\text { (Major phylum) }\end{array}$ & Major bioactive compounds & Disease prevention \\
\hline Porifera & $\begin{array}{l}\text { Manzamine, phenolic or } \\
\text { quinoid, alkaloids, terpenoids, } \\
\text { brominated tryptamines, }\end{array}$ & $\begin{array}{l}\text { Antimalarial, antiviral especially } \\
\text { AIDS, antibacterial, antifungal, } \\
\text { anticancer }\end{array}$ \\
\hline Coelenterata & $\begin{array}{l}\text { Postaglandins, proteins, } \\
\text { enzymes, steroids, terpenoids, } \\
\text { brominated alkaloids, } \\
\text { macrolides and ceramides }\end{array}$ & $\begin{array}{l}\text { antibacterial, antifungal, antialgal, } \\
\text { cariac and nerve muscle } \\
\text { relaxation, antitumour, anticancer, } \\
\text { antineoplastic }\end{array}$ \\
\hline Annelida & $\begin{array}{l}\text { Peptides, Arenecins, hedistins, } \\
\text { antimicrobial peptide (AMP), }\end{array}$ & $\begin{array}{c}\text { Arthritis, oesteoporesis, bone } \\
\text { cancer, antimicrobial, } \\
\text { antibacterial, antifungal }\end{array}$ \\
\hline Arthropoda & $\begin{array}{l}\text { Lectin viz. limulin and } \\
\text { carcinoscorpin, thiol ester } \\
\text { protein, fatty acids, } \\
\text { triglycerides, carotenoids and } \\
\text { lipids, }\end{array}$ & $\begin{array}{c}\text { Antibacterial, anti cancer, } \\
\text { antioxidant, antiproliferative, } \\
\text { antimutagenic, antiinflamatory, } \\
\text { immune response }\end{array}$ \\
\hline Mollusca & $\begin{array}{l}\text { Dolostatin, lectin, steroid, } \\
\text { terpenoids, acetylenic } \\
\text { compounds, dollstains, } \\
\text { polysaccharides }\end{array}$ & $\begin{array}{l}\text { Antleukemic, immune response, } \\
\text { hypotension, relaxation smooth } \\
\text { muscle, antinicotinic activity, } \\
\text { antiviral especially HIV virus } \\
\text { inhibiting compound }\end{array}$ \\
\hline Echinodermata & $\begin{array}{l}\text { Saponins ans sterol derivatives, } \\
\text { tarpenoids, glycoproteins, } \\
\text { cerebrosides, pyrimidine } \\
\text { nucleaosides, thymine } \\
\text { deoxyriboside and uracil } \\
\text { deoxyribose, polysaccharides, } \beta \text { - } \\
\text { carotene }\end{array}$ & $\begin{array}{l}\text { Hemolytic, antibacterial, } \\
\text { antifungal, antineoplastic, } \\
\text { antitumor, antiviral especially anti } \\
\text { HIV activity, antiinflamatory, } \\
\text { anti cancer, anti allergic }\end{array}$ \\
\hline
\end{tabular}




\section{References}

[1] Alam A.M., Sarkar S.K., Gomes A., Inflammation 33 (2012) 1223-1231.

[2] Ang K.K.H., Holmes M.J., Higa, T., Hamann, M.T., Kara U.A.K. Antimicrob Agents Chemother (2000) 1645-1649.

[3] Armstrong P.B., Swarnakar S., Srimal S., Misquith S., Hahn E.A., Aimes R.T., Quigley J.P., J Biol Chem 21 271(25) (1996) 14717-14721.

[4] Armstrong P.B., Melchior R., Swarnakar S., Quigley, J.P., Mol. Immunol. 35(1) (1998) 47-53.

[5] Anbuselvi S., Chellaram C., Sreenivasan R.S., Jonesh S., Jayanthi L., Edward J.K.P., J Med Sci 9(5) (2009) 240-244.

[6] Aneiros A., Garateix, A., J Chromatograp B 803 (2004) 41-53.

[7] Avasthi K., Chandra T., Rawat D.S., Bhakuni D.S., Indian J Chem 35B (1996) 437440.

[8] Ayer S.W., Andersen R.J., Cun-Heng H., Clardy J.J., Org Chem 49 (1984) 3869-3670.

[9] Baker J.T., Pure Appl Chem 48 (1) (1976) 35-44.

[10] Banduraga M.M., Fenical W., Donovan S.F., Clardy J.J., Am Chem Soc 104 (1982) 6463-6565.

[11] Barrero A.F., Alvarez-Manzaneda E.J., Herrador M.M., Chagboun R., Galera P., Bioorg Med Chem Lett 9 (16) (1999) 2325-2328.

[12] Basu Sarbadhikarykary S., Datta D., Bhadra R., Ind J Exp Biol (1995) 209-212.

[13] Belarbi E.H., Go'mez A.C., Chisti Y., Garci'aCamacho A., MolinaGrima E., Biotechnol Advanc 21 (2003) 585-598.

[14] Berge J.P., Bourgougnon D., Carbonnelle V.L.B., Tomansoni C., Durand P., Roussakis C., Anti-Cancer Res 17 (1997) 2115-2120.

[15] Bergmann W., Feeney R.J., J Am Chem Soc 72 (1950) 2809-2810.

[16] Bragadeeswaran S., Sri Kumaran N., Prasath Sankar P., Prabahar R., J Pharm Alternat Med 2(3) (2013) 9-17.

[17] Burkholder P.R., Sharma G.M., Lloydia 32 (1969) 466-483.

[18] Burres N.S., Barber D.A., Gunasekera S.P., Shen L.L., Clement, J.J., Biochem Pharmacol 42 (1991) 745-751.

[19] Capelle N., Brackman J.C., Daloze D., Tursch B., Bull Soc Chim 89 (1980) 399-404.

[20] Carle J.S., Christophersen C., J Am Chem Soc 102 (15) (1980) 5107-5108.

[21] Casapullo A., Minale L., Zollo F.J., Nat Prod 56 (1993) 527-533.

[22] Chain B.M., Anderson R.S., Biol Bull 164 (1983) 41-49.

[23] Chellaram C., Gnanambal K.M., Edward J.K.P. Ind J Mar Sci 33 (2004) 369-372.

[24] Chellaram C., Sreenivasan R.S., Jonesh S., Anand T.P., Edward J.K.P., Biotechnol 8 (2009) 456-461.

[25] Chen J., SPC Beche-de-mer Inf Bull 18 (2003) 18-23. 
[26] Cimino G., De Stefano S., Minale L., Tetrahedron 29 (1973) 2565-2570.

[27] Cimino G., De Stefano S., Minale L., Experientia 31 (10) (1975) 1117-1118.

[28] Cimino G., DeStefano S., De Rosa S., Sodano G., Villani G., Bull Soc Chem Belg 89 (12) (1980) 1069-1073.

[29] Coleman J.E., De Silva E.D., Kong F., Anderson R.J., Tetrahedron Lett 51 (1995) 10653-10662.

[30] Crews P., Bescansa P., Bakus G.J., Experimentia 41 (1985) 690-691.

[31] Datta D., Chowdhury A., Swarnakar S., In search of carbohydrate binding protein from peanut worm, P. archuata found at Sunderbans mangrove, India. 2nd International Meet on Advanced Studies on Cell Signaling Network (CeSiN). CSIRIndian Institute of Chemical Biology, Kolkata, India. December 13-15 (2014) PP No 28 pp87.

[32] De Silva E.D., Scheuer P.J., Tetrahedron Lett 21 (1980) 1611-1614.

[33] De Silva E.D., Scheuer P.J., Tetrahedron Lett. 22 (1981) 3147-3150.

[34] Dhinakaran D.I., Lipton, A.P., SpringerPlus 3 (2014) 673. doi:10.1186/2193-1801-3673.

[35] Djerassi C., Theobald N., Kokke W.C.M.C., Pak C.S., Carlson R.M.K., Pure Appl Chem 51 (1979) 371.

[36] Djura P., Stierle D.B., Sullivan B., Faulkner D.J., Arnold E., Clardy J.J., Org Chem 45 (1980) 1435-1441.

[37] Duh C.Y., Wang S.K., Chu M.J., Sheu J.H., J Nat Prod 61 (1998) 1022-1024.

[38] Edrada R.A., Proksch P., Wray V., Witte L., Müller W.E., Van Soest R.W., J Nat Prod 59(11) (1996) 1056-1060.

[39] Elayaraja S., Murugesan P., Vijayalakshmi S., Balasubramanian T., Indian J Mar Sci 39(2) (2010) 257-261.

[40] Erickson K.L., In: Marine Natural Products (edited by P. J. Scheuer), Academic Press, NewYork 5 (1983) p. 131.

[41] Faulkner D. J., Nat Prod Rep 12 (1995) 75-125.

[42] Faulkner D.J., Nat Prod Rep 19 (2002) 1-48.

[43] Fenical W., McConnel O., Experientia 31 (1975) 1004-1005.

[44] Fuesetani N., Basel Karger publisher (2000) 1-5.

[45] Fusetani N., Matsunaga S., Konosu S., Tetrahedron Lett 22 (1981) 1985-1988.

[46] Fuhrman F.A., Fuhrman G.J., Kim Y.H., Pavelka L.A., Mosher H.S., Science 207 (4427) (1980) 193-195.

[47] Fuhrman F.A., Fuhrman G.J., Nachman R.J., Mosher H.S., Science 212 (1981) 88-90.

[48] Funel C., Berrue F., Roussakis C., Fernandez-Rodriguez, R., Amade, P., J Nat Prod 67 (2004) 491-494.

[49] Garcia M.M., Diaz M., Valdes, Marine drugs 5 (2007) 52-70. 
[50] Gonzalez A.G., Estrada D.M., Martin J.D., Martin V.S., Perez C., Perez R., Tetrahedron 40 (20) (1984) 4109-4113.

[51] Groweiss A., Fenical W., Cun-Heng H., Clardy J., Zhongde W., Zhongnian Y., Kanghov L., Tetrahedron Lett 26 (1985) 2379-2386.

[52] Grozinger K., Freter K.R., Farina P., Gladezuk A., Eur J Med Chem Chim Ther 18 (1983) 221.

[53] Gunasekera S.P., Schmitz F.J., J Org Chem 48 (1983) 5157.

[54] Gunasekera S.P., Gunasekera R., Longly E., Schulte, G.K., J Org Chem 56 (1991) 1346.

[55] Gustafson K., Andersen R.J., Tetrahedron 41 (1985) 1101-1108.

[56] Hamel E., Sackett D.L., Vourloumis D., Nicolaou K.C., Biochem 38 (1999) 54905498.

[57] Hanmann M.T., Scheuer P.J., Kahalide, F., J American Chem Soc 115 (1993) 58255826.

[58] Hanmann M.T., Otto C.S., Scheuer P.J. Dunbar D.C., J Org Chem 61 (1996) 65946600 .

[59] Hardoim C.C., Costa R., Mar Drugs 12 (10) (2014) 5089-5122.

[60] Harrigan G.G., Luesch H., Yoshida W.Y., Moore R.E., Nagle D.G., Paul V.J., Mooberry S.L., Corbett T.H., Valeriote F.A., J Nat Prod 61 (9) (1998) 1075-1077.

[61] Hegde V.R., Chan T.M., Pu H., Gullo V.P., Patel M.G., Das P., Wagner N., Parameswaran P.S., Naik C.G., Bioorg Med Chem Lett 12 (2002) 3203-3205.

[62] Herecia F., Ubeda A., Life Sci 62(9) (1998) 115-120.

[63] Himayaa S.W.A., Ryua B, Qian Z.J., Kwon K.S., Environ Toxicol Pharm 10 (2010) 1016.

[64] Hirota K., Kubo K., Kitade Y., Maki Y., Tetrahedron Lett 26 (1985) 2355.

[65] Hoye T.R., Caruso A. J., Dellaria J.F. Jr., Kurth M.J.J., Am Chem Soc 104 (1982) 6704.

[66] Hurley J.C., Tosolini F.A., Louis W.J., J Clinc Pathol 44(10) (1991) 849-854.

[67] Ishibashi H., Ishihara K., Yamamoto H.J., Am Chem Soc 126 (2004) 11122.

[68] Jaspars M., Horton P.A., Madrid L.H., Crews P., J Nat Prod 58 (1995) 609.

[69] Jimeno J.M. Anti-cancer Drugs 13Supp 11 (2002) S15-S19.

[70] Johnson J.A., Citarasu T., Manjusha W.A. J Chem Biol Physic Sci 2 (4) (2012) 18421848 .

[71] Kim, Y. G.; Nachman, R. J.; Pavelka, L.; Mosher, H. S.; Fuhrman, F. A.; Fuhrman, G. J. J. Nat. Prod. 44 (1981) 206.

[72] Kimuchi H., Tsukitani Y., Shimizu I., Kobayashi M., Kitagawa I., Chem Pharm Bull (Japan) 29 (1981) 1492.

[73] Kimuchi H., Tsukitani Y., Shimizu I., Kobayashi M., Kitagawa I., Chem Pharm Bull (Japan) 31 (1983) 552. 
[74] Kimura A., Nakgawa H., Toxicon 18 (1980) 689.

[75] Kingston D.G., J Nat Prod 72 (2009) 507-515.

[76] Kiran N., Siddiqui G., Khan A.N., Ibrar K., Tushar, P., J Clinc Cell Immunol 5 (2014) 1 doi.org/10.4172/2155-9899.1000189.

[77] Kobayashi J., Nakamura H., Hirata Y., Ohizumu Y., Biochem Biophys Res Commun 105 (1982) 1389.

[78] Kobayashi M., Lee N.K., Son B.W., Yanagi K., Kyogoku Y., Kitagawa I., Tetrahedron Lett 25 (1984) 5925.

[79] Komori T., Sanechika Y., Ito Y., Matsuo J., Nohara T., Kawasaki T., Schulten H.R., Liebigs Ann Chem (1980) 653.

[80] Kosuge T., Tsuji K., Hirari K., Yamaguchi K., Okamoto T., Itaka Y., Tetrahedron Lett 22 (1981) 3417.

[81] Kosuge T., Tsuji K., Hirai K., Chem Pharma Bull (Japan) 30 (1982) 3255.

[82] Kuramoto M., Miyake N., Ishimaru Y., Ono N., Uno, H., Org Lett 10 (2008) 54655468.

[83] Laport M.S., Santos O.C., Muricy, G., Curr Pharm Biotechnol 10 (2009) 86-105.

[84] Leung M., Stefano, G.B., Life Sci 33 (Supl. 1) (1983) 77.

[85] Leung M., Stefano G.B., Proc Natl Acad Sci USA 81 (1984) 955.

[86] Li L., Wang C.Y., Huang H., Mollo E., Cimino G., Guo Y.W., Helv Chim Acta 91 (2008) 111-117.

[87] Litchfield C., Liaasen-Jenen S., Comp Biochem Physiol 66B (1980) 359.

[88] Lindel T., Jensen P.R., Fenical W., Long B.H., Casazza A.M., Carboni J., Fairchild C.R., J Am Chem Soc 119 (1997) 8744-8745.

[89] Linhardt R.J., Loganathan D., Al-Hakim A., J Med Chem 33 (1990) 1639-1645.

[90] Liu H., Namikoshi M., Meguro S., Nagai H., Kobayashi H., Yao X.J., Nat Prod 67 (2004) 472.

[91] Lombardo T., Blanco, G.A., Int J Cell Biol 2012 (2012) 7 pages Article ID 280675.

[92] Long B.H., Carboni J.M., Wasserman A.J., Cornell L.A., Casazza A.M., Jensen P.R., Lindel T., Fenical W., Fairchild C.R., Cancer Res 58 (1998) 1111-1115.

[93] López-Saiz C.M., Suárez-Jiménez G.M., Plascencia-Jatomea M., Burgos-Hernández A., Mar Drugs 11(10) (2013) 3926-3950.

[94] Loya S., Kashman Y., Hizi A., Arch Biochem Biophys 293 (1992) 208.

[95] Luesch H., Harrigan G.G., Goetz G., Horgen F.D., Curr Med Chem 9 (2002) 1791.

[96] Lysek N., Kinscherf R., Claus R., Lindel T.Z., Naturforsch [C] 58 (2003) 568.

[97] Marinlit, Version September A marine literature database produced and maintained by Department of chemistry, University of Catenbury, New Zealand (2007). (www.chem.Cauterbury.ac hz/marin lit/marinlitshtml).

[98] Maripandi A., Prakash Ali L., Al-Salamah A., Adv Biotech 9(9) (2010) 24-28. 
[99] May W.S., Sharkis S.J., Esa A.H., Gebbia V., Kraft A.S., Pettit G.R., Sensenbrenner L.L., Proc Natl Acad Sci USA 84 (1987) 8483-8487.

[100] McCarthy P.J., Pomponi S.A. Marine Biomed Res (2004) 1-2.

[101] McConnell O., Longley R.E., Koehn F.E., The discovery of Natural products with therapeutic potential. Butterworth-Heinemann, Boston V.P Gullo (eds) (1994) 109174.

[102] McDaid H.M., Bhattacharya S.K., Chen X.T., He L., Shen H.J., Gutteridge C.E., Horwitz S.B., Danishefsky S.J., Cancer Chemother Pharmacol 44 (1999) 131-137.

[103] Miller J.H., Singh A.J., Northcote P.T. Mar Drugs 8 (2010) 1059-1079.

[104] Minale L., Riccio R., Sodano G., Tetrahedron Lett (1974) 3401.

[105] Moore R.E., Blackman A.J., Cheuk C.E., Mynderse J.S., Matsumoto G.K., Clardy J., Woodard R.W., Craig J.C.J., Org Chem 49 (1984) 2848.

[106] Mukku V.J., Edrada R.A., Schmitz, F.J.; Shanks, M.K.; Chaudhuri, B.; Fabbro D.J. Nat Prod 66 (2003) 686.

[107] Mynderse J.K., Moore M., Kashiwagi M., Norton T., Sci 196 (1997) 538-540.

[108] Nakasu T., Walker R.P., Thompson J.E., Faulkner D.J., Experientia 39 (1983) 789.

[109] Nieman J.A., Coleman J.E., Wallace D.J., Piere E., Lim L.Y., Roberge M., Anderson R.J., J Nat Prod 66 (2003) 183-199.

[110] Ovchinnikova T.V., Aleshina S.V., Baladin A.D., FEBS Lett 577 (2004) 209-214.

[111] Pan W., Liu X., Ge F., Han J., Zheng T., J Biochem 135 (2004) 297-304.

[112] Park H.W., Choi S.U., Baek N.I., Kim S.H., Eun J.S., Yang J.H., Kim D.K.., Arch Pharm Res 29 (2006) 131-134.

[113] Patra A., Chan C.W.J., Scheuer P.J., Dyne G.D., Van Matsumoto G.K., Clardy J.J., Am Chem Soc 106 (1984) 7981.

[114] Pettit G.R., Kamano Y., Fuji Y., Herald C.L., Inoue M., Brown P., Gust D., Kitahara K., Schmidt J.M., Doubek D.L., Michel C.J., Nat Prod 44 (1981) 482.

[115] Pettit G.R., Rideout J.A., Hasler J.A., Doubek D.L., Reucroft P.R., J Nat Prod 44 (1981a) 713.

[116] Pettit G.R., Hasler J.A., Paul K.D., Herald C.L.J., Nat Prod 44 (1981b) 701.

[117] Pettit G.R., Herald C.L., Doubek D.L., Herald D.L., Arnold E., Clardy J.J., Am Chem Soc 104 (1982) 6846.

[118] Pettit G.R., Herald C.L., Kamano Y., Gust D., Aoyagi R.J., Nat Prod 46 (1983a) 528.

[119] Pettit G. R., Herald C.L., Kamano Y.J., Org Chem 48 (1983b) 5354.

[120] Pimenta A.M., De Lima M.E. J Pept Sci 11(11) (2005) 670-676.

[121] Pomponi S.A., J Biotechnol 70 (1999) 5-13.

[122] Prassas I., Diamandis E.P., Nat Rev Drug Discov 7 (2008) 926-935.

[123] Poncet J., Curr Pharm Des 5 (1999) 139.

[124] Prassas I., Diamandis E.P. Nat Rev Drug Discov 7 (2008) 926-935. 
[125] Proksch P., Edrada E., Appl Microbiol Biotechnol 59 (2002) 125-134.

[126] Rahman M.A., Arshad A., Md. Yusoff F., Sea Urchins (Echinodermata: Echinoidea): Their Biology, Culture and Bioactive Compounds. Int. Conf. Agricultural, Ecological and Medical Sciences (AEMS-2014) July 3-4 London (UK) (2014) Doi.org/10.15242/ IICBE.C714075.

[127] Ravichandran S., Kathiresan K., Hemalatha Balaram, Biotechnol Mol Biol Rev 2 (2) (2007) 033-038.

[128] Rosser R.M., Faulkner D.J.J., Org Chem 49 (1984) 5157.

[129] Roy M.C., Tanaka J., de Voogd N., Higa T.J., Nat Prod 65 (2002) 1838.

[130] Saito S.Y., Prog Mol Subcell Biol 46 (2009) 187-219.

[131] Santhana Ramasamy M., Murugan A., J Shellfish Res 24(1) (2005) 243-251.

[132] Santoro P., Parisi G., Guerriero V., Boll Soc Ital Biol Sper 66 (1990) 1237.

[133] Schmitz F.J., Gopichand Y., Michaud D.P., Prasad R.S., Ramaley S., Hossain M.B., Rahman A., Sengupta P.K., Van Der Helm D., Pure Appl Chem 51 (1981) 853.

[134] Schmitz F.J., Lakshmi V., Powell D.R., Helm V.D.J., Org Chem 49 (1984) 241.

[135] Schmitz F.J., Bowden B.F., Toth S.I., Antitumor and cytotoxic compounds from marine organism. In Marine Technology Vol 1. Pharmaceutical and Bioactive Natural Products. Attaway D. H. and Zaborsky O.R (Eds.), Plenum Press, New York, (1993) pp. 197-308.

[136] Schwartz E.F., Mourao C.B., Moreira K.G., Camargos T.S., Mortari M.R. Biopolym 98(4) (2012) 385-405.

[137] Scheuer P. J., Ed Bioorganic Marine Chemistry, Vol. 2, Springer, Verlag, New York (1988).

[138] Schulter G., Scheuer P.J., McConnel O.J., Helv Chim Acta 63 (1980) 2159.

[139] Shanmugam A., Mahalakshmi T.S., Barwin V., J fish Aquat Sci 3(5) (2008) 268-274.

[140] Shimizu Y., In Marine Biotechnology Attaway D. H. and Zaborsky O. R. (Eds.), Plenum Press, New York Volume 1 (1993) 391-410.

[141] Sima P., Vetvicka V., World J Clin Oncol 10 2(11) (2011) 355-361.

[142] Simmons T.L., Andrianasolo E., McPhail K., Flatt P., Gerwick W.H., Mol Cancer Therap 4 (2005) 333-342.

[143] Sivasubramanian K., Ravichandran S., Kumaresan M., Asian Pacif J Tropic Med (2011) 310-314.

[144] Slate D.L., Lee R.H., Rodriguez J., Crews P., Biochem Biophys Res Commun 203 (1995) 260.

[145] Sliwka H.R., Nokleby O.W., Liaaen-Jensen S., Acta Chem Scand B 41 (1987) 245.

[146] Sokoloff S., Haley S., Usieli V., Colorni A., Sarel S., Experientia 38 (1982) 337.

[147] Stonik V.A., Pure Appl Chem 58 (1986) 243.

[148] Su J.H., Wen Z.H., Mar Drugs 9 (2011) 944-951.

[149] Sullivan G., Djura P., Mclutyre D.E., Faulkner D.J., Tetrahedron 37 (1981) 979. 
[150] Sullivan G., Faulkner D.J., Webb L., Science 221 (1983) 1175.

[151] Swarnakar S., Chowdhury P.S., Sarkar, M., Biochem. Biophys. Res. Commun.178 (1991) 85-94.

[152] Talapatra S.N., Nandy A., Banerjee K., Verma S., Swarnakar, S., Biochemical characterization of fiddler crab, Uca rosea collected from east coast of India. 2nd International Meet on Advanced Studies on Cell Signaling Network (CeSiN). CSIRIndian Institute of Chemical Biology, Kolkata, India. December 13-15 PP No - 34 (2014) pp93.

[153] Talpir P.Y., Benayahu Y., Kashman Y., Schleyer L.P., Tetrahedron Lett 35 (1994) 4453-4456.

[154] Tasiemski A.D., Schikorski F., Croq M. le., Van camp C., Wichlacz B., Sautiere P.E., Dev Comp Immunol 31 (2007) 749-762.

[155] Taylor K.M., Baird-Lambert J.A., Davis P.A., Spence I., Fed Proc Fed Am Soc Exp Biol 40 (1981) 15.

[156] Tincu J.A., Taylor S.W., Antimicrob Agents Chemother 48 (10) (2004) 3645-3654.

[157] Towle M.J., Salvato K.A., Budrow B.F., Wels G., Kuznetsov K.A., Aalfs S., Cancer Res 61 (2001) 1031-1021.

[158] Townsend E., Moni R., Quinn R., Parsons P.G., Melanoma Res (1992) 349.

[159] Tsukamoto S., Tatsuno M., van Soest R.W., Yokosawa H., Ohta T.J., Nat Prod 66 (2003) 1181.

[160] Tymiak A.A., Rinehart K.L.Jr., J Am Chem Soc 105 (1983) 7396.

[161] Vennila R., Rajesh kumar R.K., Kanchana S., Arumugam M., Balasubramanian T., African J Biochem Res 5(1) (2011) 14-21.

[162] Willams D.H., Stone M.J., Hanch P.R., Rhaman S.K., J Nat Prod 52 (1989) 11891208.

[163] Wright J.L.C.J., Nat Prod 47 (1984) 893-895.

[164] Wu J., Yi Y.H., Tang H.F., Chem Biodivers 3(11) (2006) 1249-1254.

[165] Yasuda F., Tada H., Experientia 37 (1981) 110-111.

[166] Zapata A., Amemiya C.T., Microb Immun 248 (2000) 67-107.

[167] Zhang W., Guo Y.W., Gu, Y., Curr Med Chem 13 (2006) 2041-2090.

[168] Zhang S.Y., Yi Y.H., Tang H.F., J Nat Prod 69(10) (2006) 1492-1495.

[169] Zhou J., Giannakakou P., Curr Med Chem Anticancer Agents 5 (2005) 65-71.

[170] Zou Z., Yi Y., Wu H., Yao L., Jiuhong, L.D., J Nat Prod 68(4) (2005) 540-546. 